\title{
Peptide Growth Factors Can Provoke "Fetal" Contractile Protein Gene Expression in Rat Cardiac Myocytes
}

\author{
Thomas G. Parker, Sharon E. Packer, and Michael D. Schneider \\ Molecular Cardiology Unit, Departments of Medicine, Cell Biology, and Physiology \\ and Molecular Biophysics, Baylor College of Medicine, Houston, Texas 77030
}

\begin{abstract}
Cardiac-specific gene expression is intricately regulated in response to developmental, hormonal, and hemodynamic stimuli. To test whether cardiac muscle might be a target for regulation by peptide growth factors, the effect of three growth factors on the actin and myosin gene families was investigated by Northern blot analysis in cultured neonatal rat cardiac myocytes. Transforming growth factor- $\beta 1$ (TGF $\beta 1,1 \mathrm{ng} / \mathrm{ml}$ ) and basic fibroblast growth factor (FGF, $25 \mathrm{ng} / \mathrm{ml}$ ) elicited changes corresponding to those induced by hemodynamic load. The "fetal" $\beta$-myosin heavy chain (MHC) was up-regulated about fourfold, whereas the "adult" $\alpha$ MHC was inhibited $>50-60 \%$; expression of $\alpha$-skeletal actin increased approximately twofold, with little or no change in $\alpha$-cardiac actin. Thus, peptide growth factors alter the program of differentiated gene expression in cardiac myocytes, and are sufficient to provoke fetal contractile protein gene expression, characteristic of pressureoverload hypertrophy. Acidic FGF (25 ng/ml) produced sevento eightfold reciprocal changes in MHC expression but, unlike either TGF- $\beta 1$ or basic FGF, inhibited both striated $\alpha$-actin genes by 70-90\%. Expression of vascular smooth muscle $\alpha$ actin, the earliest $\alpha$-actin induced during cardiac myogenesis, was increased by all three growth factors. Thus, three $\alpha$-actin genes demonstrate distinct responses to acidic vs. basic FGF. (J. Clin. Invest. 1990. 85:507-514.) actin • myosin • fibroblast growth factor $\bullet$ transforming growth factor- $\beta 1 \cdot$ cardiac hypertrophy
\end{abstract}

\section{Introduction}

Cardiac hypertrophy provoked by a hemodynamic load comprises not only a quantitative increase in overall organ mass, individual myocyte volume, protein content and total RNA transcription, but also characteristic qualitative changes, including the expression of diverse sarcomeric, cytosolic, and membrane proteins as their embryonic isoforms (1). Up-regulation of the "fetal" contractile proteins, $\beta$-myosin heavy chain $\left(\beta \mathrm{MHC}^{1} ; 2,3\right)$ and $\alpha$-skeletal actin $(\alpha \mathrm{SkA} ; 4,5)$, are perhaps

A preliminary report of this research was presented at the annual meeting of the American Federation for Clinical Research, Washington, DC, May 1989, and has been published in abstract form (1989. Clin. Res. 37:284A).

Address reprint requests to Dr. Schneider, Molecular Cardiology Unit, Baylor College of Medicine, One Baylor Plaza, Room 506C, Houston, TX, 77030.

Received for publication 19 May 1989 and in revised form 8 September 1989.

1. Abbreviations used in this paper: aFGF and bFGF, acidic and basic fibroblast growth factor; $\alpha \mathrm{CaA}, \alpha$-cardiac actin; $\alpha \mathrm{MHC}$ and $\beta \mathrm{MHC}, \alpha-$

J. Clin. Invest.

(C) The American Society for Clinical Investigation, Inc.

0021-9738/90/02/0507/08 \$2.00

Volume 85, February 1990, 507-514 the most intensively studied of this ensemble. In principle, the transition from compensatory hypertrophy to intractable failure may in part be due to anomalous transcription of genes that encode proteins essential for cardiac function. However, while $\beta \mathrm{MHC}$ are thought to diminish myocardial contractility, on the basis of slower cross-brige cycling (6), the possible physiologic implications of altered actin expression have not been proven. Thus, the changes produced by hemodynamic stress may recapitulate a fetal program whose elements share regulatory events, rather than adaptation, in common $(5,7)$.

Little is known of the specific transduction pathways through which pressure overload can coordinately regulate an ensemble of "embryonic" or "fetal" genes. Mechanical stimulation including passive stretch (8), or hormones induced by aortic constriction (9), may themselves induce hypertrophy or alter gene expression. There is increasing evidence that such signals might be coupled to cardiac mass through oncogeneencoded nuclear proteins such as c-fos and c-myc $(5,7,10,11)$, which have been implicated in the transduction of signals triggered by peptide growth factors (reviewed in references 12,13 ). A potential role for peptide growth factors in cardiac hypertrophy, including transforming growth factor- $\beta 1$ (TGF $\beta 1 ; 14)$ and the heparin-binding acidic and basic fibroblast growth factors (aFGF, bFGF; 15), has been suggested by their presence in developing and adult cardiac myocytes or the extracellular matrix. Furthermore, growth factor production increases in myocytes surviving coronary artery ligation (16), and autocrine or paracrine factors which accumulate in the myocardium during pressure-overload hypertrophy can stimulate cardiac growth in vitro (17).

That cardiac myocytes might be targets for the action of peptide growth factors also is suggested by the responses of skeletal muscle cells. Both bFGF and aFGF are potent mitogens for skeletal myoblasts (18) and block the onset of the myogenic phenotype in undifferentiated cells, apparently differing only in potency $(18,19)$. In contrast, TGF $\beta 1$ suppresses the induction of muscle-specific proteins including MHC and $\alpha$-actin (20-23) in the absence of proliferative growth $(21,22)$. These effects may occur at least in part by preventing the appearance or activity of certain muscle-specific DNA-binding proteins which modulate transcription (24). Conversely, TGF $\beta 1$ (21) and bFGF (25) also can down-regulate the muscle phenotype in myocytes which have not undergone terminal (irreversible) differentiation, whereas myocytes which are committed to fusion and the postmitotic state are reported to be refractory to the action of TGF $\beta 1(20,21)$ and bFGF (18) on muscle-specific genes.

However, it remains conjectural whether cellular events involved in growth factor signal transduction in fact play a role in cardiac hypertrophy triggered by pressure overload. First,

and $\beta$-myosin heavy chain; $\alpha$ SkA, $\alpha$-skeletal actin; $\alpha$ SmA, $\alpha$-vascular smooth muscle actin; TGF $\beta 1$, type $\beta$-1 transforming growth factor. 
the specific actions of serum growth factors are contingent both on cell type (26) and developmental state (27). Extensive disparities distinguish cardiac development from that of skeletal muscle and other existing model systems, of which the most noteworthy, perhaps, are the ability to synthesize cardiac-specific proteins without exiting the cell cycle (28), the uncoupling of DNA synthesis from mitotic division shortly after birth (29), and, eventually, adaptive growth by cell enlargement (30). At least one oncogene which extinguishes the ability of skeletal muscle to differentiate, SV40 large T antigen (31), by contrast is permissive for a differentiated phenotype in cardiac myocytes (32). Moreover, recent reports demonstrate that commitment of pluripotent cells to the skeletal muscle pathway during embryogenesis may be conferred by a hierarchy of myogenic "determination" genes (33), most of which show homology to the nuclear oncogene c-myc, including MyoD1 (34) and myogenin $(35,36)$. In contrast, MyoD1 and myogenin are not expressed in cardiac muscle $(34,36)$, and the molecular mechanisms underlying cardiac ontogeny are not yet known. Together, these intrinsic differences suggest the likelihood that even genes which are co-expressed both by cardiac and skeletal myocytes must be subject to regulatory events which are lineage-specific. Genes such as $\alpha$-cardiac actin $(\alpha \mathrm{CaA})$ and $\alpha$-SkA, which are targets for the action of peptide growth factors, might thus be expected to possess responses to growth factor binding that differ fundamentally in the environment of cardiac vs. skeletal muscle cells. Finally, significant differences are known to exist among contractile protein gene families in their response to particular trophic signals. For example, unlike the MHC genes, $\alpha-\mathrm{CaA}$ and $\alpha-\mathrm{SkA}$ are relatively insensitive to fluctuations in thyroid hormone concentration (37).

Accordingly, the specific objectives of the present investigation were to: $(a)$ determine if cardiac myocytes in culture are targets for the suppressive effects of peptide growth factors on adult contractile protein gene expression; (b) establish if peptide growth factors can, in addition, elicit "fetal" contractile protein gene expression ( $\alpha \mathrm{SkA}, \beta \mathrm{MHC}$, or both), as seen with pressure-overload hypertrophy; and $(c)$ ascertain whether alterations in contractile protein gene expression necessarily are accompanied by increased total RNA, protein content, or cell number in myocardial cell cultures.

\section{Methods}

Cell culture. Primary cultures of cardiac myocytes were prepared from the ventricles of 2-d-old Sprague-Dawley rats by enzymatic dissociation in $0.1 \%$ trypsin, $0.1 \%$ collagenase, and $0.025 \%$ DNAase (Worthington Biochemical Corp., Freehold, NJ). Cells were pooled in medium (Dulbecco's modified Eagle's medium/Ham's nutrient mixture F12 [1:1; Gibco Laboratories, Grand Island, NY], adjusted to $17 \mathrm{mM}$ $\mathrm{NaHCO}_{3}, 2 \mathrm{mM}$ L-glutamine, and $50 \mu \mathrm{g} / \mathrm{ml}$ gentamicin) supplemented with $10 \%$ fetal bovine serum (Hyclone Laboratories, Logan, UT). The cell population was partially depleted of mesenchymal cells by differential adhesiveness. Nonadherent cells were plated at $10^{5}$ cells $/ \mathrm{cm}^{2}$ on $100-\mathrm{mm}$ polystyrene dishes coated with $0.1 \%$ gelatin (ICN Biochemicals, Irvine, CA). After $24 \mathrm{~h}$, the cells were washed and subjected to serum withdrawal for $48 \mathrm{~h}$ in serum-free medium supplemented with $1 \mu \mathrm{g} / \mathrm{ml}$ insulin, $5 \mu \mathrm{g} / \mathrm{ml}$ transferrin, $1 \mathrm{nM} \mathrm{LiCl}, 1 \mathrm{nM}$ $\mathrm{Na}_{2} \mathrm{SeO}_{4}, 25 \mu \mathrm{g} / \mathrm{ml}$ ascorbic acid, and $1.0 \mathrm{nM}$ thyroxine. The thyroid hormone concentration and cell density were higher than in a previous study (27) to ensure a more physiologic concentration and rate of contraction, respectively. Thereafter, cells were incubated for $24 \mathrm{~h}$ in serum-free medium plus vehicle (control) or supplemented with TGF $\beta 1(1 \mathrm{ng} / \mathrm{ml})$, bFGF $(25 \mathrm{ng} / \mathrm{ml})$, or aFGF $(25 \mathrm{ng} / \mathrm{ml})$. The final concentrations for components of the vehicle applied to cultured myocytes were $4 \mu \mathrm{M} \mathrm{HCl}, 10^{-7} \mathrm{vol} / \mathrm{vol}$ Triton X-100 and $1 \mu \mathrm{g} / \mathrm{ml}$ bovine serum albumin.

Myocyte-depleted mesenchymal cultures prepared from the rapidly adherent $(30 \mathrm{~min})$ fraction of ventricular cells were maintained for 5-7 d in F12 supplemented with $10 \%$ fetal bovine serum, passaged once at a 1:20 dilution, and subjected at confluency to mitogen withdrawal in the same serum-free medium utilized for the cardiac myocytes. Secondary cultures were utilized to overcome the limitation of residual myocytes found in primary mesenchymal cultures.

Acidic and basic FGF (R\&D Systems, Minneapolis, MN) each were purified from bovine brain by three cycles of Heparin-Sepharose affinity chromatography, followed by immunoadsorption of the irrelevant peptide, and were at least $96 \%$ homogeneous by amino acid analysis. TGF $\beta 1$ was used as the homodimer isolated from porcine platelets (R\&D Systems).

$R N A$ isolation and Northern blot hybridization. Total cellular RNA was isolated by the guanidinium thiocyanate-phenol-chloroform method (38) and quantitated by spectrophotometry. To minimize variance in the yield of RNA, each sample was pooled from four independent cultures. Yield was consistent between experiments (for four control cultures, the standard error of the mean was $\sim 6 \%$ of the observed value). Aliquots ( $15 \mu \mathrm{g}$ per lane) were size-fractionated by formaldehydeagarose gel electrophoresis, and transferred to nylon membranes. To investigate actin and MHC gene expression, synthetic oligonucleotides were prepared to isoform-specific $3^{\prime}$ untranslated sequences, as described previously $(27,37) . \alpha$-Smooth actin $(\alpha \mathrm{SmA})$ mRNA was identifying using a synthetic probe corresponding to $3^{\prime}$ untranslated nucleotides 1195-1216 (39). Probes were labeled at the $5^{\prime}$ end with $\left[\gamma-{ }^{32} \mathrm{P}\right] \mathrm{ATP}$ using T4 polynucleotide kinase, to a specific activity of $4-6 \times 10^{8} \mathrm{cpm} / \mu \mathrm{g}$. Blots were washed for $45 \mathrm{~min}$ in $6 \times$ SSC at room temperature and $20 \mathrm{~min}$ in $6 \times \mathrm{SSC} / 1 \% \mathrm{SDS}$ at $42^{\circ} \mathrm{C}$. Blots were exposed to XAR-2 film (Eastman Kodak Co., Rochester, NY) at $70^{\circ} \mathrm{C}$ with intensifying screens and were quantitated by scanning densitometry.

Protein and creatine kinase determinations. Cell pellets were disrupted using a Potter-Elvehjem homogenizer, in $0.32 \mathrm{M}$ sucrose, 10 $\mathrm{mM}$ Tris- $\mathrm{HCl}$ (pH 8.0), and $5 \mathrm{mM} \beta$-mercaptoethanol. Total protein content was determined by the Bradford technique (40). Creatine kinase isoenzymes were resolved on $1 \%$ agarose gels (Corning Medical, Medfield, MA) in Tris-barbital buffer. Electrophoresis was carried out at $4^{\circ} \mathrm{C}$ for $20 \mathrm{~min}$ at $170 \mathrm{~V}$. The gels were overlaid with Rosalki agent (Corning Medical) with creatine phosphate (Boehringer Mannheim Biochemicals, Indianapolis, IN) as substrate, photographed under ultraviolet illumination, and analyzed by scanning densitometry (41). MM, MB, and BB denote the "muscle" homodimer, heterodimer, and "brain" homodimer, respectively.

Cell number. To determine cell number, myocyte cultures were incubated in $0.1 \%$ trypsin for $10 \mathrm{~min}$ ( $>98 \%$ viable single cells). Mesenchymal cell cultures were incubated with trypsin for 12-15 min. Each plates was washed three times in phosphate-buffered saline to remove residual adherent cells, and complete removal of the cell populations was confirmed by phase-contrast microscopy. Cell counts then were obtained on the single cell suspensions using a hemocytometer, counting at least 200 cells for each of two replicate measurements of each independent sample.

Statistical procedures. Experimental results were compared by the unpaired two-tail $t$ test and Scheffe's multiple comparison test for single factor analysis of variance, using a significance level of $P<0.05$.

\section{Results}

Cardiac myocytes plated at $10^{5}$ cells $/ \mathrm{cm}^{2}$ formed a functional syncytium (100-140 contractions per min) within $24 \mathrm{~h}$ in serum-free medium. To characterize the extent of myocardial differentiation in vitro, actin and MHC gene expression were 

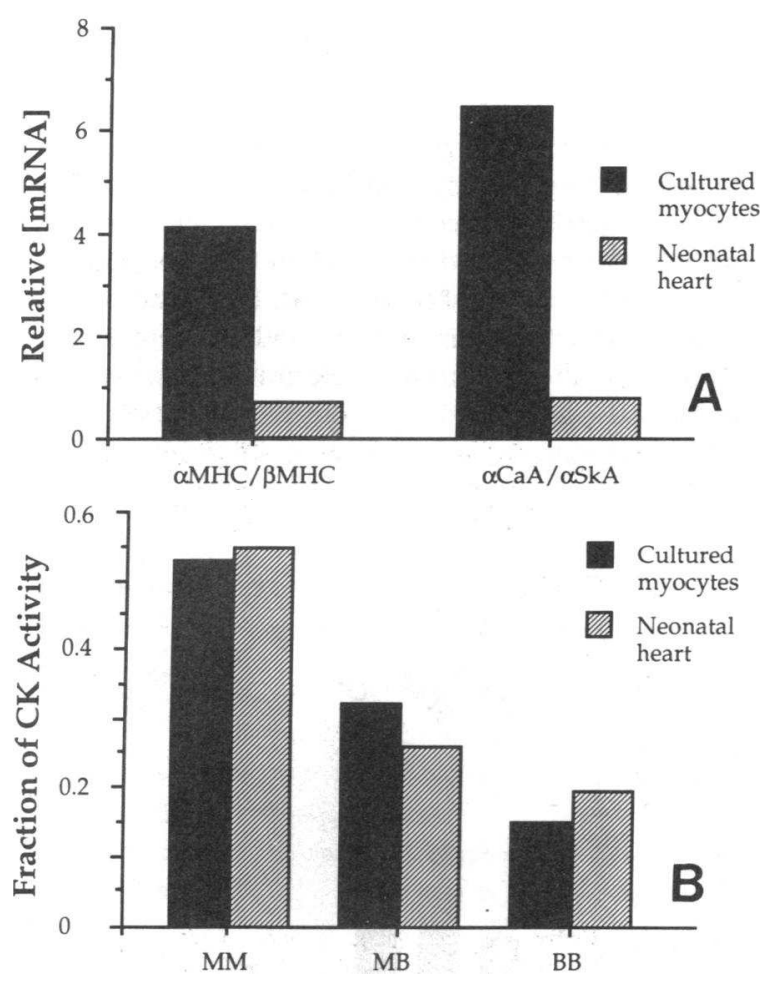

Figure 1. Cultured cardiac myocytes possess differentiated phenotypic properties. $(A)$ RNA blot hybridization was performed as described in Methods, and the relative hybridization signal of $\alpha \mathrm{MHC}$ and $\alpha \mathrm{CaA}$ to $\beta \mathrm{MHC}$ and $\alpha \mathrm{SkA}$, respectively, is shown for cultured myocytes (solid bar) vs. the neonatal (2-d-old) rat heart in vivo (gray bar). Corresponding ratios for MHC and sarcomeric actins in the adult rat heart were at least 10 and 20 , respectively. $(B)$ The distribution of creatine kinase isoenzymes in cultured myocytes (solid bars) was comparable to that seen in the intact neonatal heart (gray bars). Corresponding values for the adult rat heart were: MM $60 \%$, MB $27 \%$, BB $13 \%$. analyzed by Northern hybridization after $48 \mathrm{~h}$ in serum-free medium and $24 \mathrm{~h}$ in serum-free medium supplemented with the diluent used for growth factor studies. As shown in Fig. 1 $A$, the relative hybridization signal for $\alpha \mathrm{MHC}$ vs. $\beta \mathrm{MHC}$ mRNA was about fivefold greater in cultured cardiac myocytes than in age-matched samples of neonatal rat heart in vivo (4.10:0.8). To exclude the possibility that the preferential expression of $\alpha \mathrm{MHC}$ was merely due to the concentration of thyroxine in the serum-free medium, steady-state levels of $\alpha$ actin mRNA also were analyzed. In overall agreement with the results for MHC gene expression, the relative intensity of $\alpha \mathrm{CaA}$ vs. $\alpha \mathrm{SkA}$ was about ninefold greater in the cultured cardiac myocytes than was found in the intact heart (6.47:0.670). Thus, the proportional expression of both $\alpha \mathrm{MHC}$ and $\alpha \mathrm{CaA}$ was augmented in the dissociated, cultured cells. As shown in Fig. $1 B$, the distribution of creatine kinase isoenzymes expressed in culture was similar to that found in neonatal and adult ventricular muscle. Taken together, these data indicate that cultured cardiac myocytes possess differentiated phenotypic properties which are at least appropriate to the cells' developmental stage.

To investigate whether developmentally regulated gene expression in cardiac muscle cells might be susceptible to control by one or more specific growth factors, contractile protein gene expression was analyzed in ventricular myocytes cultured for $72 \mathrm{~h}$ as described above, after $24 \mathrm{~h}$ in the presence of TGF $\beta 1$, bFGF, aFGF, or vehicle. Results in parentheses are shown relative to levels of expression in control cells. In partial agreement with their ability to suppress sarcomeric gene expression in skeletal muscle, TGF $\beta 1$ and bFGF each inhibited expression of the "adult" $\alpha \mathrm{MHC}$ gene by $>50 \%$ (TGF $\beta 1$, 0.34 ; bFGF, 0.47; Fig. 2). Conversely, each growth factor markedly stimulated the "fetal" $\beta$ MHC gene approximately fourfold (TGF $\beta 1,4.09$; bFGF, 4.29). aFGF produced reciprocal changes in MHC expression qualitatively similar to, but greater than, those provoked by the other growth factors
A

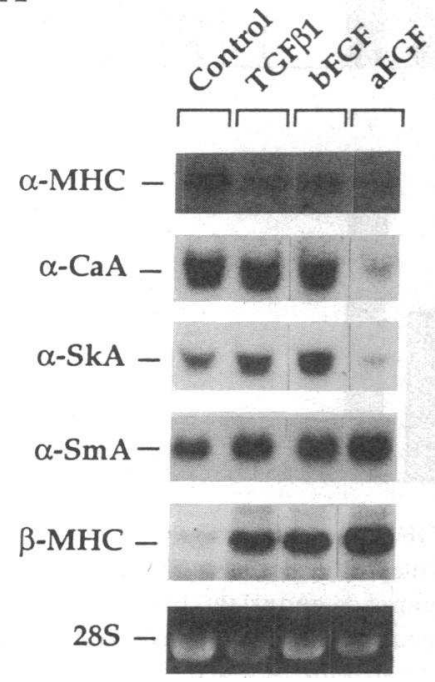

B

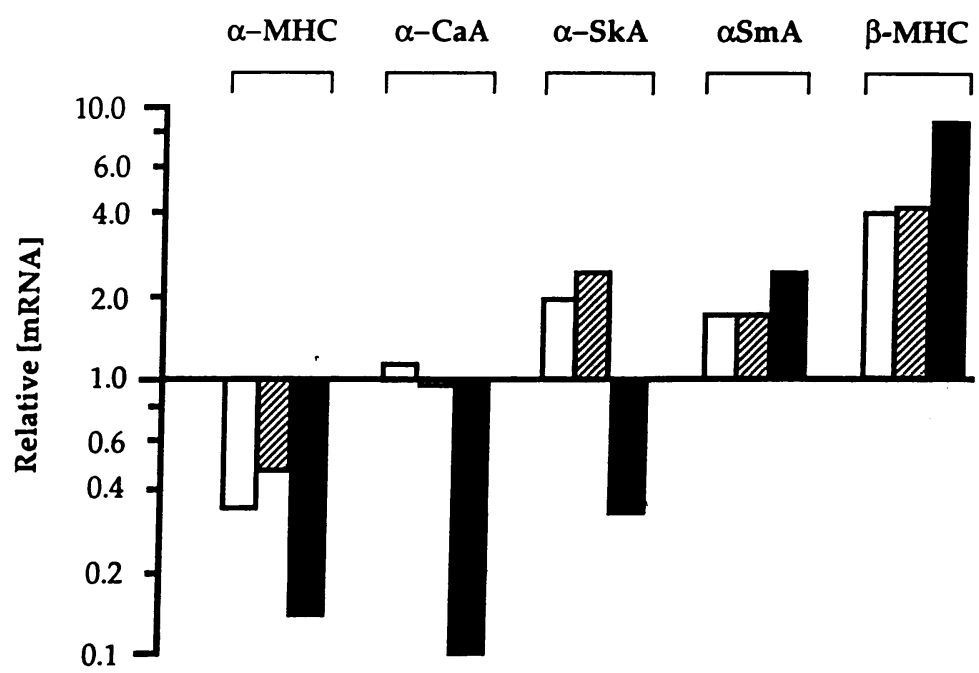

Figure 2. Peptide growth factors exert selective and differential effects on contractile protein gene expression in cardiac muscle. (A) Myocardial gene expression was analyzed by Northern blot hybridization in cardiac myocytes subjected to TGF $\beta 1$, bFGF, or aFGF for $24 \mathrm{~h}$. Ethidium-bromide stained $28 \mathrm{~S}$ ribosomal RNA is shown for comparison. $(B)$ Results for five contractile protein genes were quantitated by scanning densitometry and are shown relative to expression in control cells treated with serum-free medium and vehicle alone. (Open bar) TGF $\beta 1 ;$ (hatched bar) bFGF; (solid bar) aFGF. 
( $\alpha \mathrm{MHC}, 0.14 ; \beta \mathrm{MHC}, 8.71$ ). Whereas exogenous thyroid hormone prevents the transition between MHC isoforms after aortic constriction in vivo (3), all three peptide growth factors, at the concentration tested, produced down-regulation of $\alpha \mathrm{MHC}$ and up-regulation of $\beta \mathrm{MHC}$ despite the presence of 1 $\mathrm{nM}$ thyroxine in the medium.

All three peptide growth factors also provoked changes in $\alpha$-actin gene expression, which were distinct from the reciprocal regulation each produced in the MHC genes (Fig. 2). Whereas neither TGF $\beta 1$ nor bFGF significantly altered $\alpha \mathrm{CaA}$ transcript availability (TGF $\beta 1,1.17$; bFGF, 0.97$)$, both growth factors stimulated approximately twofold expression of the $\alpha$ SkA gene, whose expression is associated with the embryonic or hypertrophic heart. Similar results were obtained in each of two independent experiments. Thus, in cardiac myocytes, four contractile protein genes exhibit a continuum of responses to TGF $\beta 1$ and bFGF, and the effects evoked were highly concordant. In contrast, aFGF differed in its consequences for expression of these sarcomeric actin.genes, and was a potent inhibitor of both $\alpha \mathrm{CaA}$ and $\alpha \mathrm{SkA}$ in cultured cardiac myocytes.

A third sarcomeric actin, $\alpha \mathrm{SmA}$, is expressed in cardiac myocytes prior to the induction of either cardiac or skeletal actin (42). This ontogenic relationship among the $\alpha$-actin genes suggests two mutually exclusive hypotheses: that aFGF might suppress all three $\alpha$-actin genes or, alternatively, that it might selectively stimulate $\alpha \mathrm{SmA}$, in the context of a phenotype even more primitive than that provoked by the other peptides. As shown in Fig. 2, $\alpha \mathrm{SmA} \mathrm{mRNA}$ levels were increased by all three growth factors, and the greatest increase in $\alpha \mathrm{SmA}$ expression was induced by aFGF (TGF $\beta 1,1.69$; bFGF, 1.75; aFGF, 2.45). Neither basal expression of $\alpha \mathrm{SmA}$ nor its up-regulation by growth factors was detected in myocyte-depleted cultures enriched for cardiac mesenchymal cells (Fig. 3). Similarly, these growth factors did not induce $\alpha \mathrm{SkA}$ or $\alpha \mathrm{CaA}$

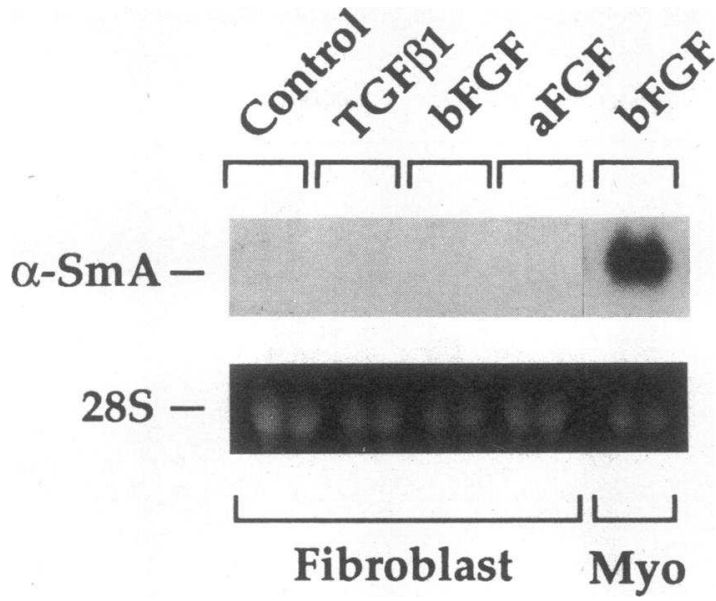

Figure 3. Up-regulation of $\alpha \mathrm{SmA}$ gene expression in myocardial cell cultures does not entail its induction in fibroblastic cells. Myocytedepleted (Fibroblast) cultures were incubated for $48 \mathrm{~h}$ in the serumfree medium, and treated for $24 \mathrm{~h}$ with diluent (control) or the peptide growth factors indicated. $\alpha \mathrm{SmA}$ gene expression was analyzed by Northern blot hybridization (cf. Fig. 2). For comparison, RNA isolated from cardiac myocytes treated with bFGF is shown at the right $(M y o)$. Ethidium-bromide stained 28S ribosomal RNA is shown below. in the fibroblastic cells (Parker, T. G., and M. D. Schneider, unpublished observations; cf. reference 26 ).

To examine the hypothesis that the differing effects of aFGF on contractile protein gene expression might be associated with distinct effects on myocardial growth in vitro, total RNA, protein content, and cell number were examined in myocardial cell cultures treated with each of the three peptides at the concentrations shown above (Fig. 4). RNA and protein content were analyzed in four and five independent experiments, respectively, and cell number determined in seven. The interval examined was limited, to avoid the potentially confounding effect of sustained fibroblast proliferation and the contingency that longer exposure to a given factor might alter

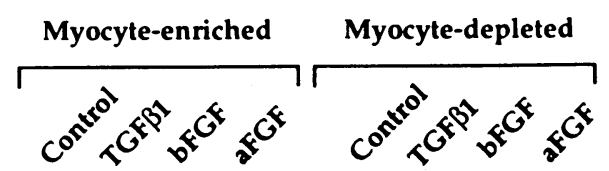

A

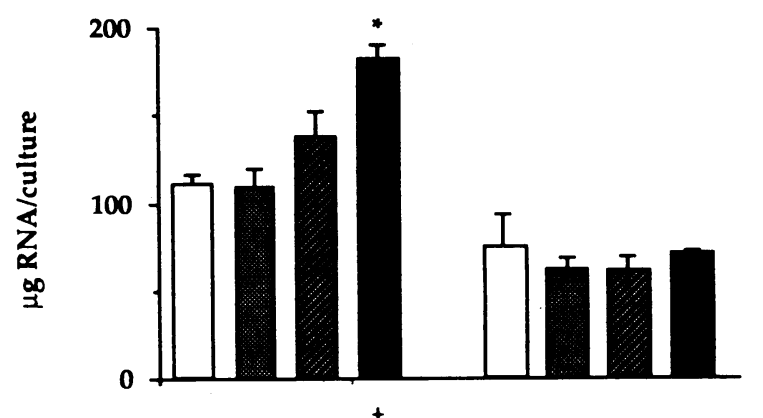

B
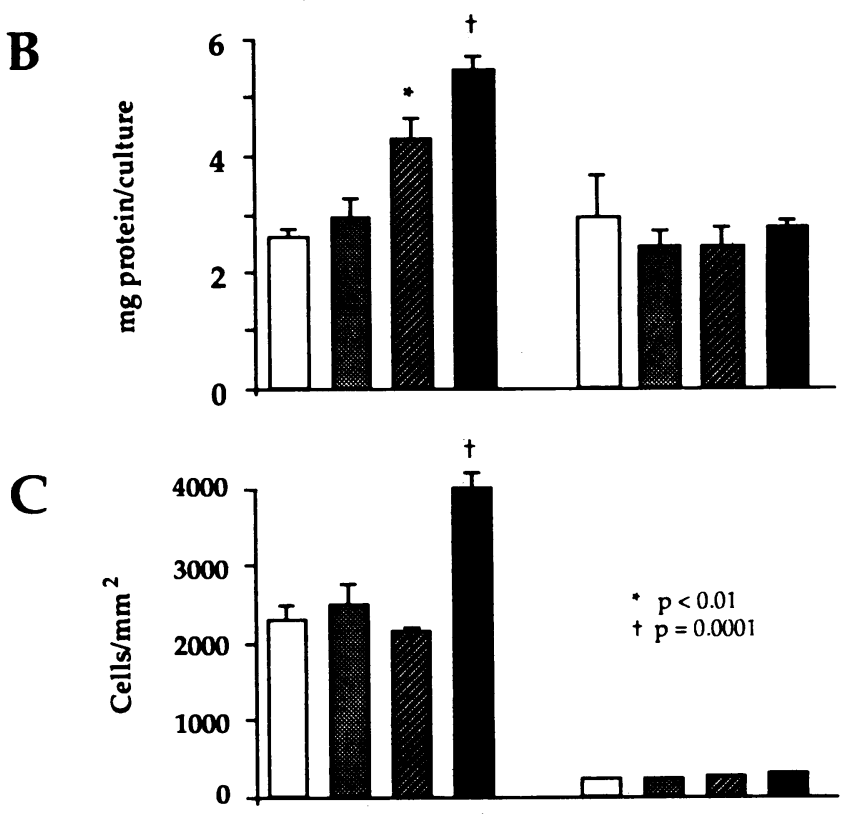

Figure 4. TGF $\beta 1$, bFGF, and aFGF elicit dissimilar growth responses in myocardial cells. $(A)$ Total cellular RNA, $(B)$ protein, and (C) cell number. (Left) Myocyte-enriched and (right) myocyte-depleted cultures prepared from neonatal rat ventricles were cultured in serum-free medium for $48 \mathrm{~h}$ and treated for $24 \mathrm{~h}$ with vehicle or purified growth factors as described. The mean $\pm \mathrm{SE}$ is shown, except RNA and protein in myocyte-depleted cultures are mean \pm SD. $P$ values are indicated for all comparisons with vehicle-treated control cultures where analysis of variance was significant by Scheffe's test ( ${ }^{*} P<0.01{ }^{\dagger} P=0.001$ ). (Open bar) control; (gray bar) TGF $\beta 1$; (hatched bar) bFGF; (solid bar) aFGF. 
the cells' growth responses as a consequence of dedifferentiation. In spite of its demonstrated effects on actin and MHC expression, TGF $\beta 1$ did not increase RNA, protein, or cell number, in agreement with the fact that TGF $\beta 1$ is a potent regulator of differentiated gene expression in skeletal muscle which exerts neither positive nor negative effects on myocyte growth $(21,22)$.

Although bFGF provoked changes in contractile protein gene expression similar both qualitatively and quantitatively to those produced by TGF $\beta 1$, bFGF increased protein content at $24 \mathrm{~h}$ by $65 \%$ relative to control $(4.27 \pm 0.36$ vs. $2.59 \pm 0.16 \mu \mathrm{g}$ per culture; $P=0.0029$ ). During the interval tested, no effect of bFGF on cell number was seen; differences in RNA content, similarly, were not statistically significant. These observations concur with evidence that bFGF increases cardiac myocyte number $<30 \%$ even after $7 \mathrm{~d} \mathrm{(43)}$ and elicits mitotic growth in skeletal myocytes only in the presence of serum concentrations higher than those used here (18). In contrast, at $24 \mathrm{~h}$, aFGF had stimulated protein content more than twofold $(5.47 \pm 0.22 \mu \mathrm{g}$ per culture; $P=0.0001)$, increased total RNA by $46 \%$ ( $110 \pm 5.6$ vs. $161 \pm 12.6 \mu$ g per culture; $P=0.0098)$, and increased cell number $\sim 75 \%(2,290 \pm 180$ vs. $3,980 \pm 318$ cells $/ \mathrm{mm}^{2} ; P=0.0001$ ). To exclude a preponderant effect of aFGF and bFGF on the residual nonmuscle cells, confluent myocyte-depleted cultures were examined for comparison (cf. references 10,$27 ; n=2$ for RNA and protein; $n=6$ for cell number). RNA and protein content in the myocyte-depleted "fibroblast" cultures were comparable to those in parallel myocyte-enriched cultures, despite differences in cell number per square millimeter. After $48 \mathrm{~h}$ in the same serum-free medium used for cardiac myocytes and $24 \mathrm{~h}$ of growth factor stimulation, neither RNA, protein, nor cell number in mesenchymal cultures differed from the control values (Fig. 4). Despite the potential for discordance between mesenchymal cells in the myocyte-depleted vs. myocyte-enriched cultures, these comparisons argue against the interpretation that the growth responses observed in cardiac "myocytes" occur chiefly or exclusively in the nonmuscle cells.

\section{Discussion}

Successful application of in vitro methods to the molecular biology of cardiac growth has been impeded by the absence of permanent cell lines, by evidence that conventional cell culture methods fail to maintain a fully differentiated phenotype, and by the paucity of physiologically relevant agonists. The investigations reported here demonstrate that cardiac myocytes are, directly or indirectly, targets for the action of three peptide growth factors: TGF $\beta 1$, bFGF, and aFGF. Differentiated ventricular muscle cells possessed complex, selective responses to both TGF $\beta 1$ and bFGF: up-regulation of both "fetal" isoforms, $\alpha$ SkA and $\beta \mathrm{MHC}$; down-regulation of $\alpha \mathrm{MHC}$ expression; and little or no change in $\alpha \mathrm{CaA}$. Thus, either peptide alone was sufficient to elicit a program of altered gene expression which diverges from the apparently uniform suppression found in skeletal muscle cells and strongly resembles events characteristic of pressure overload in vivo. Other ligands which alter contractile protein gene expression in cardiac myocytes fail to correspond so precisely to hypertrophy produced by load.

By contrast, aFGF inhibited the expression of the cardiac and skeletal actin genes in ventricular myocytes. Few, if any, qualitative differences have been reported previously in the action of basic versus acidic FGF in a given cell lineage (44-46). Both aFGF and bFGF repress muscle creatine kinase in skeletal myoblasts (19) and, conversely, induce the conversion of ectoderm to mesodermal muscle progenitor cells in Xenopus embryos (47). Thus, the action of these growth factors is contingent on cell maturation, as well as lineage. Where differences in their potency have been examined, aFGF was 20 - to 100 -fold less active than bFGF $(44,46)$. Acidic FGF inhibits striated $\alpha$-actin gene expression even at $1.25 \mathrm{ng} / \mathrm{ml}$, 20 -fold lower than the concentration of bFGF tested here (Parker, T. G., and M. D. Schneider, unpublished results). In contrast, $\alpha \mathrm{SmA}$ mRNA levels were increased by all three growth factors. Studies utilizing the recombinant proteins would test the interpretation that the observed disparities between the action of acidic and basic FGF on cardiac myocytes are intrinsic to these peptides, and not the result of minor contaminants. The apparent association between proliferative growth and down-regulation of the striated $\alpha$-actin genes merits additional investigation. By comparison, aFGF failed to provoke growth in myocyte-depleted cultures. While anomalous responses are unlikely in fibroblasts which have been passaged only once, the possibility exists that growth properties differ subtly between cardiac fibroblasts in primary vs. secondary culture, and it therefore will be useful to examine growth regulation in low-density cardiac cultures, where cell identity can be more readily ascertained (10).

The present data are consistent with the previous observation that serum exerts multifunctional effects on cardiac growth and actin gene expression which vary with the myocytes' precise stage of differentiation (27), and suggest the testable hypothesis that the ability of ventricular muscle cells to respond to aFGF declines during the transition from hyperplastic to hypertrophic growth. The relative expression of acidic and basic FGF by cardiac myocytes may itself be developmentally regulated (15). As illustrated by disparities in the action of adrenergic agonists on ventricular muscle cells at different developmental stages $(9,48)$, the differentiated phenotype of neonatal cardiac myocytes after stringent mitogen withdrawal does not necessarily predict that adult cardiac muscle cells share all, if any, of the responses to growth factors exhibited by younger cells.

The precise role of peptide growth factors during hypertrophy in the intact animal or man also remains a matter of conjecture. For example, TGF $\beta$ suppresses the growth of endothelial cells in monolayer culture (49) but stimulates angiogenesis in vivo (50). Moreover, the possible complexities of autoregulation and cooperative interaction among these growth factors in the heart have not yet been explored. These unanswered questions may have particular interest in view of recent studies demonstrating both the existence of TGFs (14) and FGFs (15) in cardiac muscle cells during development, as well as the up-regulation of TGFs (16) and FGFs (51) after myocardial infarction or chronic ischemia. A role for cardiac growth factors during embryogenesis has been suggested in formation of the cardiac valves (52) and commitment of splanchnic mesoderm to the cardiac lineage (53), akin to the synergistic action of FGF and TGF $\beta$ analogues in skeletal muscle ontogeny $(26,47)$. TGF $\beta 1(54)$ and the FGFs $(44)$ are the prototypes for two multigene families of peptides with complex and diverse effects on cell growth, differentiation, and morphogenesis: homologues including TGF $\beta 3$ and $-\beta 4$ also may be expressed in cardiac muscle cells (55). 
The findings reported here suggest the provisional hypothesis that peptide growth factors which exist in cardiac myocytes and their extracellular matrix may contribute to cardiac hypertrophy and the associated "fetal" phenotype, through autocrine or paracrine mechanisms. Peptide growth factors might also be expected to affect nonmuscle components of the myocardium, through fibroblast proliferation or accumulation of the extracellular matrix, and add to the interstitial fibrosis which is often a hallmark of pathologic hypertrophy. The clinical relevance of TGF $\beta$ for disease states and tissue repair has been recently reviewed (54). The selective and heterogeneous actions shown by these peptide growth factors also might contribute to topographic or temporal discrepancies in the appearance of fetal myosin and actin transcripts (56).

Finally, these results may provide evidence of previously unanticipated disparities between the program of differentiation in skeletal vs. cardiac muscle. In skeletal muscle, serum factors uniformly suppress all sarcomeric actin and MHC genes before irreversible differentiation $(57,58)$, and are not thought to modify muscle-specific gene expression once terminal differentiation has occurred $(18,20,21,57,58)$. In cardiac myocytes, on the other hand, TGF $\beta 1$ and bFGF selectively inhibited the "adult" $\alpha \mathrm{MHC}$ transcript, concurrent with upregulation of all three fetal contractile protein genes examined thus far. This intricate set of events perhaps is most simply interpreted in the context of a lineage-specific action of TGF $\beta 1$ and bFGF on ventricular myocytes. Alternatively, the use of coding-sequence probes $(57,58)$ may have obscured possible transitions among the highly conserved actin and MHC isoforms, in myotubes exposed to mitogenic medium. Despite the fact that muscle cell receptors for both TGF $\beta 1$ (59) and FGFs (60) down-regulate dramatically upon terminal differentiation, L6E9 myotubes remain able to up-regulate the fibronectin and collagen genes after treatment with TGF $\beta 1$ (20), as well as c-myc after exposure to serum (58). The myogenic determination gene MyoD1 is not constitutively expressed within the skeletal muscle lineage (cf. reference 34 ), but rather can be repressed by FGFs and TGF $\beta 1$ (61) or other inhibitors of muscle differentiation $(62,63)$. Furthermore, the induction of myogenin itself accompanies growth factor withdrawal (36). Together, such observations are consistent with the inference that these nuclear proteins participate directly in the control of muscle-specific genes by growth factors. However, in cardiac muscle cells no protein with a corresponding structure and function has yet been identified. Cellular ras oncogenes produce a phenotype comparable to that provoked by TGF $\beta 1$ (62-66) and suppress $\alpha$-actin gene expression in skeletal muscle cells $(62,64)$. It will be intriguing to determine whether activated ras alleles, by contrast, might selectively stimulate the transcription of $\alpha \mathrm{SmA}, \alpha \mathrm{SkA}$, or both when introduced into cardiac myocytes. Future attempts to interpret our results in the context of growth factor-inducible muclear oncogenes and other ubiquitous transcription factors will need to account for the disparate effects of these peptide growth factors on myocardial gene expression.

\section{Acknowledgments}

We thank L. Chan for oligonucleotide synthesis; D. L. Friedman for assistance with creatine kinase analysis; V. Mahdavi, M. B. Perryman, and R. J. Schwartz for helpful criticisms; E. N. Olson and R. B. Runyon for discussions of their unpublished results; F. Ervin for technical assistance; and S. Terry for preparation of the manuscript. We thank $R$. Roberts for generous support and encouragement.

This investigation was supported by grants to Dr. Schneider from the American Heart Association, Texas Affiliate (85G-223, 87R-179) and the National Institutes of Health (HL-39141). Dr. Parker is funded as a Fellow of the Medical Research Council of Canada and is a Fellow of the American Heart Association-Bugher Foundation Center for Molecular Biology of the Cardiovascular System. Dr. Schneider is an Established Investigator of the American Heart Association.

\section{References}

1. Swynghdauw, B. 1986. Developmental and functional adaptation of contractile proteins in cardiac and skeletal muscles. Physiol. Rev. 66:710-7149.

2. Lompré, A. M., K. Schwartz, A. Swynghedauw, G. Lacombe, N. Van Thiem, and B. Swynghedauw. 1979. Myosin isoenzyme distribution in chronic heart overload. Nature (Lond.). 282:105-107.

3. Izumo, S., A.-M. Lompré, R. Matsuoka, G. Koren, K. Schwartz, B. Nadal-Ginard, and V. Mahdavi. 1987. Myosin heavy chain messenger RNA and protein isoform transitions during cardiac hypertrophy. J. Clin. Invest. 79:970-977.

4. Schwartz, K., D. de la Bastie, P. Bouveret, P. Oliviero, S. Alonso, and M. Buckingham. 1986. $\alpha$-Skeletal muscle actin mRNAs accumulate in hypertrophied adult rat hearts. Circ. Res. 59:551-555.

5. Izumo, S., B. Nadal-Ginard, and V. Mahdavi. 1988. Proto-oncogene induction and reprogramming of cardiac gene expression produced by pressure overload. Proc. Natl. Acad. Sci. USA. 85:339-343.

6. Schwartz, K., Y. Lecarpentier, J. L. Martin, A. M. Lompré, J. J. Mercadier, and B. Swynghedauw. 1981. Myosin isoenzyme distribution correlates with speed of myocardial contraction. J. Mol. Cell. Cardiol. 13:1071-1075.

7. Mulvagh, S. L., L. H. Michael, M. B. Perryman, R. Roberts, and M. D. Schneider. 1987. A hemodynamic load in vivo induces cardiac expression of the cellular oncogene, c-myc. Biochem. Biophys. Res. Commun. 147:627-636.

8. Kaida, T., I. Komuro, and Y. Yazaki. 1988. Increased protein synthesis and myosin isoform change in cultured cardiocytes by loading. Circulation. 78:II-242.

9. Bishopric, N., P. C. Simpson, and C. P. Ordahl. 1987. Induction of the skeletal $\alpha$-actin gene in $\alpha_{1}$-adrenoreceptor-mediated hypertrophy of rat cardiac myocytes. J. Clin. Invest. 80:1194-1199.

10. Starksen, N. F., P. C. Simpson, N. Bishopric, S. R. Coughlin, W. M. F. Lee, J. Escobedo, and L. T. Williams. 1986. Cardiac myocyte hypertrophy is associated with c-myc protooncogene expression. Proc. Natl. Acad. Sci. USA. 83:8348-8350.

11. Komuro, I., M. Kurabayashi, F. Takaku, and Y. Yazaki. 1988. Expression of cellular oncogenes in the myocardium during the developmental stage and pressure-overloaded hypertrophy of the rat heart. Circ. Res. 62:1075-1079.

12. Schneider, M. D., and E. N. Olson. 1988. Control of myogenic differentiation by cellular oncogenes. Mol. Neurobiol. 2:1-39.

13. Simpson, P. C. 1989. Proto-oncogenes and cardiac hypertrophy. Annu. Rev. Physiol. 51:189-202.

14. Thompson, N. L., K. C. Flanders, J. M. Smith, L. R. Ellingsworth, A. B. Roberts, and M. B. Sporn. 1989. Expression of transforming growth factor- $\beta 1$ in specific cells and tissues of adult and neonatal mice. J. Cell Biol. 661-669.

15. Weiner, H. L., and J. L. Swain. 1989. Acidic fibroblast growth factor mRNA is expressed by cardiac myocytes in culture and the protein is localized to the extracellular matrix. Proc. Natl. Acad. Sci. USA. 86:2683-2687.

16. Thompson, N. L., F. Bazoberry, E. H. Speir, W. Casscells, V. J. Ferrans, K. C. Flanders, P. Kondaiah, A. G. Geiser, and M. B. Sporn. 1989. Transforming growth factor beta-1 in acute myocardial infarction in rats. Growth Factors. 1:91-99.

17. Hammond, G. L., E. Wieben, and C. L. Markert. 1979. Molec- 
ular signals for initiating protein synthesis in organ hypertrophy. Proc. Natl. Acad. Sci. USA. 76:2455-2459.

18. Clegg, C. H., T. A. Linkhart, B. B. Olwin, and S. D. Hauschka. 1987. Growth factor control of skeletal muscle differentiation: commitment to terminal differentiation occurs in G1 phase and is repressed by fibroblast growth factor. J. Cell Biol. 105:949-956.

19. Lathrop, B., E. Olson, and L. Glaser. 1985. Control by fibroblast growth factor of differentiation in the $\mathrm{BC} 3 \mathrm{H} 1$ muscle cell line. $J$. Cell Biol. 100:1540-1547.

20. Massague, J., T. Cheifetz, S. Endo, and B. Nadal-Ginard. 1986. Type $\beta$ transforming growth factor is an inhibitor of myogenic differentiation. Proc. Natl. Acad. Sci. USA. 83:8206-8210.

21. Olson, E. N., E. Sternberg, J. S. Hu, G. Spizz, and C. Wilcox. 1986. Regulation of myogenic differentiation by type beta transforming growth factor. J. Cell Biol. 103:1799-1805.

22. Florini, J. R., A. B. Roberts, D. Z. Ewton, S. L. Falen, K. C. Flanders, and M. B. Sporn. 1986. Transforming growth factor- $\beta$ : a very potent inhibitor of myoblast differentiation, identical to the differentiation inhibitor secreted by Buffalo rat liver cells. J. Biol. Chem. 261:16509-16513.

23. Caffrey, J. M., A. M. Brown, and M. D. Schneider. 1989. $\mathrm{Ca}^{2+}$ and $\mathrm{Na}^{+}$currents in developing skeletal myoblasts are expressed in a sequential program: reversible suppression by transforming growth factor beta-1: an inhibitor of the myogenic pathway. J. Neurosci. 9:3443-3453.

24. Buskin, J. N., and S. D. Hauschka. 1989. Identification of a muocyte nuclear factor that binds to the muscle-specific enhancer of the mouse muscle creatine kinase gene. Mol. Cell. Biol. 9:2627-2640.

25. Spizz, G., J.-S. Hu, and E. N. Olson. 1987. Inhibition of myogenic differentiation by fibroblast growth factor does not require persistent c-myc expression. Dev. Biol. 123:500-507.

26. Kimelman, D., and M. Kirschner. 1987. Synergistic induction of mesoderm by FGF and TGF- $\beta$ and the identification of an mRNA coding for FGF in the early Xenopus embryo. Cell. 51:869-877.

27. Ueno, H., M. B. Perryman, R. Roberts, and M. D. Schneider. 1988. Differentiation of cardiac myocytes following mitogen withdrawal exhibits three sequential stages of the ventricular growth response. J. Cell Biol. 107:1911-1918.

28. Rumyantsev, P. P. 1977. Interrelations of the proliferation and differentiation processes during cardiac myogenesis and regeneration. Int. Rev. Cytol. 51:187-273.

29. Clubb, J. R., F. J., and S. P. Bishop. 1984. Formation of binucleated myocardial cells in the neonatal rat: an index for growth hypertrophy. Lab. Invest. 50:571-577.

30. Zak, R., editor. 1984. Growth of the Heart in Health and Disease. Raven Press, New York. 480 pp.

31. Endo, T., and B. Nadal-Ginard. 1989. SV40 large T antigen induces reentry of terminally differentiated myotubes into the cell cycle. In Cellular and Molecular Biology of Muscle Development. L. H. Kedes and F. E. Stockdale, editors. Alan R. Liss, Inc., New York. 95-104.

32. Sen, A., P. Dunnmon, S. A. Henderson, R. D. Gerard, and K. R. Chien. 1988. Terminally differentiated neonatal rat myocardial cells proliferate and maintain specific differentiated functions following expression of SV40 large T antigen. J. Biol. Chem. 263:1913219136.

33. Pinney, D. F., S. H. Pearson-White, S. F. Konieczny, K. E. Latham, and C. P. Emerson. 1988. Myogenic lineage determination and differentiation: evidence for a regulatory gene pathway. Cell. 53:781-793.

34. Davis, R. L., H. Weintraub, and A. B. Lassar. 1987. Expression of a single transfected cDNA converts fibroblasts to myoblasts. Cell. 51:987-1000.

35. Wright, W. E., D. A. Sassoon, and V. K. Lin. 1989. Myogenin, a factor regulating myogenesis, has a domain homologous to MyoD. Cell. 56:607-617.

36. Edmondson, D., and E. N. Olson. 1989. A gene with homology to the myc similarity region of MyoD1 is expressed during myogenesis and is sufficient to activate the muscle differentiation program. Genes Dev. 3:628-640.

37. Gustafson, T. A., B. E. Markham, and E. Morkin. 1986. Effects of thyroid hormone on $\alpha$-actin and myosin heavy chain gene expression in cardiac and skeletal muscles of the rat: measurement of mRNA content using synthetic oligonucleotide probes. Circ. Res. 59:194-201.

38. Chomczynski, P., and N. Sacchi. 1987. Single-step method of RNA isolation by acid guanidinium thiocyanate-phenol-chloroform extraction. Anal. Biochem. 162:156-159.

39. McHugh, K. M., and J. L. Lessard. 1988. The nucleotide sequence of a rat vascular smooth muscle $\alpha$-actin cDNA. Nucleic Acids Res. 16:4167.

40. Bradford, M. M. 1976. A rapid and sensitive method for the quantitation of microgram quantities of protein utilizing the principle of protein-dye binding. Anal. Biochem. 72:248-254.

41. Rosalki, S. B. 1987. An improved procedure for serum creatine phosphokinase determination. J. Lab. Clin. Med. 69:696-705.

42. Ruzicka, D. L., and R. J. Schwartz. 1988. Sequential activation of $\alpha$-actin genes during avian cardiogenesis: vascular smooth muscle $\alpha$-actin gene transcripts mark the onset of cardiomyocyte differentiation. J. Cell Biol. 107:2575-2586.

43. Kardami, E., and R. R. Fandrich. 1988. Heparin-binding mitogen(s) in the heart: in search of origin and function. In Cellular and Molecular Biology of Muscle Development. Kedes, L. H. and Stockdale, F. E., editors. Alan R. Liss, Inc., New York. 315-325.

44. Gospodarowicz, D., N. Ferrara, L. Schweigerer, and G. Neufeld. 1987. Structural characterization and biological functions of fibroblast growth factor. Endocr. Rev. 8:95-114.

45. Coughlin, S. R., P. J. Barr, L. S. Cousens, L. J. Fretto, and L. T. Williams. 1988. Acidic and basic fibroblast growth factors stimulate tyrosine kinase activity in vivo. J. Biol. Chem. 263:988-993.

46. Rydel, R. E., and L. A. Greene. 1987. Acidic and basic fibroblast growth factors promote stable neurite outgrowth and neuronal differentiation in cultures of PC12 cells. J. Neurosci. 7:3639-3653.

47. Slack, J. M. W., B. G. Darlington, J. K. Heath, and S. F. Godsave. 1987. Mesoderm induction in early Xenopus embryos by heparin-binding growth factors. Nature (Lond.). 326:197-200.

48. Mann, D., and G. Cooper. 1987. Growth regulation of the adult heart: load regulation versus adrenoreceptor activation. J. Mol. Cell. Cardiol. 19:S.26. (Abstr.)

49. Muller, G., J. Behrens, U. Nussbaumer, P. Bohlen, and W. Birchmeier. 1987. Inhibitory action of transforming growth factor beta on endothelial cells. Proc. Natl. Acad. Sci. USA. 84:5600-5604.

50. Roberts, A. B., M. B. Sporn, R. K. Assoian, J. M. Smith, N. S. Roche, L. M. Wakefield, U. I. Heine, L. A. Liotta, V. Falanga, J. H. Kehrl, and A. S. Fauci. 1987. Transforming growth factor type beta: rapid induction of fibrosis and angiogenesis in vivo and stimulation of collagen formation in vitro. Proc. Natl. Acad. Sci. USA. 83:4167-4171.

51. Sharma, H. S., M. Wunsch, R. Kandolf, and W. Schaper. 1989. Angiogenesis by slow coronary artery occlusion in the pig heart: expression of different growth factor mRNAs. J. Mol. Cell. Cardiol. 21:S.24.

52. Potts, J. D., and R. B. Runyon. 1989. Epithelial-mesenchymal cell transformation in the heart can be mediated, in part, by transforming growth factor $\beta$. Dev. Biol. 134:392-401.

53. Gonzalez-Sanchez, A., J. Bisaha, C. Eisenberg, S. Wylie, and D. Bader. 1989. Commitment and diversification of cardiac progenitors. J. Cell. Physiol. 13:160. (Abstr.)

54. Roberts, A., and M. B. Sporn. 1989. The transforming growth factor-betas. In Peptide Growth Factors and Their Receptors. M. B. Sporn and A. Roberts, editors. Handbook of Experimental Pharmacology. Volume 95. Springer-Verlag, Heidelberg. 419-472.

55. Flanders, K. C., N. L. Thompson, U. I. Heine, P. Kondaiah, S. B. Jakowlew, A. G. Geiser, A. B. Roberts, F. Bazoberry, W. Casscells, V. J. Ferrans, and M. B. Sporn. 1989. Transforming growth factor-beta in the heart and in the embryo. J. Cell. Physiol. 13E:163. (Abstr.)

56. Schiaffino, S., J. L. Samuel, D. Sassoon, A. M. Lompre, I. 
Garner, F. Marotte, M. Buckingham, L. Rappaport, and K. Schwartz. 1989. Nonsynchronous accumulation of $\alpha$-skeletal actin and $\beta$-myosin heavy chain mRNAs during early stages of pressure-overload-induced cardiac hypertrophy demonstrated by in situ hybridization. Circ. Res. 64:

57. Nguyen, H. T., R. M. Medford, and B. Nadal-Ginard. 1983. Reversibility of muscle differentiation in the absence of commitment: analysis of a myogenic cell line temperature-sensitive for commitment. Cell. 34:281-293.

58. Endo T., and B. Nadal-Ginard. 1986. Transcriptional and post-transcriptional control of c-myc during myogenesis: its mRNA remains inducible in differentiated cells and does not suppress the differentiated phenotype. Mol. Cell. Biol. 6:1412-1421.

59. Ewton, D. Z., G. Spizz, E. N. Olson, and J. R. Florini. 1988. Decrease in transforming growth factor-beta binding and action during differentiation in muscle cells. J. Biol. Chem. 263:4029-4032.

60. Olwin, B. B., and S. D. Hauschka. 1988. Cell surface fibroblast growth factor and epidermal growth factor receptors are permanently lost during skeletal muscle terminal differentiation in culture. J. Cell Biol. 107:761-769.

61. Vaidya, T. B., S. J. Rhodes, E. J. Taparowsky, and S. F. Ko- nieczny. 1989. Fibroblast growth factors and transforming growth factor $\beta$ repress transcription of the myogenic regulatory gene MyoDl. Mol. Cell. Biol. 9:3576-3579.

62. Konieczny, S. F., B. L. Drobes, S. L. Menke, and E. J. Taparowsky. 1989. Inhibition of myogenic differentiation by the H-ras oncogene is associated with the down-regulation of the MyoD1 gene. Oncogene. 4:473-481.

63. Lassar, A. B., M. J. Thayer, R. W. Overell, and H. Weintraub. 1989. Transformation by activated ras or fos prevents myogenesis by inhibiting expression of MyoD1. Cell. 58:659-667.

64. Payne, P. A., E. N. Olson, P. Hsiau, R. Roberts, M. B. Perryman, and M. D. Schneider. 1987. An activated c-Ha-ras allele blocks the induction of muscle-specific genes whose expression is contingent on mitogen withdrawal. Proc. Natl. Acad. Sci. USA. 84:8956-8960.

65. Caffrey, J. M., A. M. Brown, and M. D. Schneider. 1987. Mitogens and oncogenes can block the formation of specific voltagegated ion channels. Science (Wash. DC). 236:570-574.

66. Olson, E. N., G. Spizz, and M. A. Tainsky. 1987. The oncogenic forms of N-ras or H-ras prevent skeletal myoblast differentiation. Mol. Cell. Biol. 7:2104-2111. 